\author{
KLAUDiA RACZEK ${ }^{1}$
}

\title{
Problematyka karnoprawnej ochrony życia i zdrowia w oparciu o przepisy prawa żywnościowego
}

\section{Wstęp}

W obecnym porządku prawnym Kodeks karny ${ }^{2}$ nie stanowi wyłącznego źródła prawa karnego, chociaż de iure odgrywa on dominującą rolę w tym sensie, że stanowi podstawowe źródło tego prawa. Stosowna regulacja zawarta jest w rozdziale XIX kodeksu karnego zatytułowanym „Przestępstwa przeciwko życiu i zdrowiu”, jednak czyny zabronione tam stypizowane nie stanowią wyłącznych występujących w kodeksie karnym, które za swój przedmiot ochrony miałyby życie czy zdrowie ludzkie. Dobra te usytuowane są w hierarchii dóbr chronionych $\mathrm{z}$ aksjologicznego punktu widzenia bardzo wysoko, zaś regulacja prawnokarna mająca za przedmiot ochrony życie i zdrowie znajduje się w licznych aktach prawnych tzw. pozakodeksowym prawie karnym. Kryminalizacja tych czynów coraz częściej przybiera formę czynów narażających na niebezpieczeństwo te dobra. W związku z tym mamy do czynienia z zachowaniami stwarzającymi jeszcze bardzo odległe niebezpieczeństwo, o bardzo wysokim prawdopodobieństwie zaistnienia naruszenia tych wartości ${ }^{3}$. Prawo żywnościowe jest dziedziną silnie emancypującą się z prawa rolnego. W zakresie swojej regulacji obejmuje problematykę bezpieczeństwa żywności. Ideą przewodnią, która znajduje swój normatywny wyraz jest ochrona życia i zdrowia ludzkiego jako wartości najwyższej ${ }^{4}$. Polskie prawo żywnościowe ma dość długie tradycje sięgające okresu międzywojennego. Intensyfikacja prac nastąpiła jednak w związku z akcesją Polski do Unii Europejskiej. Wynikało to z konieczności przejęcia całego acquis communautaire i konieczności zharmonizowania norm prawa krajowego z aktami

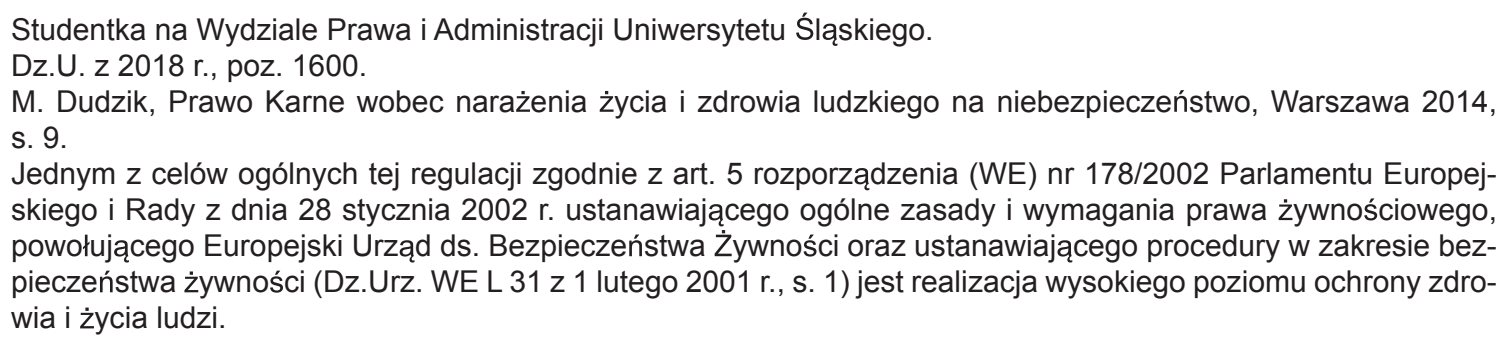
skiego i Rady z dnia 28 stycznia 2002 r. ustanawiającego ogólne zasady i wymagania prawa żywnościowego, powołującego Europejski Urząd ds. Bezpieczeństwa Żywności oraz ustanawiającego procedury w zakresie bezpieczeństwa żywności (Dz.Urz. WE L 31 z 1 lutego 2001 r., s. 1) jest realizacja wysokiego poziomu ochrony zdrowia i życia ludzi. 
legislacji unijnej ${ }^{5}$. W ujęciu komparatystycznym należy stwierdzić, że rożne są środki, za pomocą których państwa gwarantują przestrzeganie wyznaczonych standardów ochronnych - od metody cywilistycznej, przez administracyjną, aż po sankcje karne. Wybór rozwiązania adekwatnego uzależniony jest od uwarunkowań systemowych. Zgodne ze stanowiskiem przyjętym przez Trybunał Konstytucyjny brak stosownej sankcji powoduje, że przepis staje się martwy, a niespetnianie obowiazku nagminne $e^{6}$. Polski ustawodawca stojąc przed wyborem sięgnął po najdalej ingerującą i najbardziej opresyjną sankcję karną. Konstruowanie norm sankcjonowanych prawa karnego wymaga zachowania wielu gwarancji, które stanowią zasady podstawowe dla tej dziedziny prawa. W dalszej części artykułu przybliżę problemy, które niesie ze sobą normatywny model przyjęty przez ustawodawcę, który to model stanowi swoistą „mozaikę” możliwych rozwiązań.

\section{2. Życie i zdrowie jako dobra prawnie chronione}

Nie ulega wątpliwości, że w hierarchii dóbr prawnie chronionych życie ludzkie, a obok niego zdrowie stanowią najwyższe wartości. Tym samym wszelkie możliwe wątpliwości co do ich ochrony powinny być rozstrzygane in dubio pro vita humana. O doniosłości ,prawa do życia” świadczy fakt, iż jego ochrona stanowi przedmiot zainteresowania nie tylko ustawodawcy krajowego, ale również doznaje ochrony na gruncie międzynarodowym, czego przykładami są art. 3 Powszechnej Deklaracji Praw Człowieka z 1948 roku, art. 6 ust. 1 Międzynarodowego Paktu Praw Obywatelskich i Politycznych, czy art. 2 Europejskiej Konwencji Praw Człowieka ${ }^{7}$. Również polski ustrojodawca w art. 38 oraz art. 68 Konstytucji Rzeczypospolitej Polskiej z 2 kwietnia 1997 roku wskazuje na prawną ochronę życia i zdrowia. Ochrona ta dotyczy każdego życia, zatem a contrario nikt nie może dokonywać bezprawnych zamachów na te dobra. Teza o równoważności życia każdego człowieka znajduje również swoje odzwierciedlenie w judykatach - i tak Sąd Najwyższy przyjął, że życie każdego człowieka niezależnie od wieku, stanu zdrowia, reprezentowanego poziomu wiedzy, kultury, stanu rodzinnego i realnej społecznej przydatności jest wartościq uniwersalnq bez żadnego przymiotnika i podlega jednakowej ochronie prawnej $^{8}$. Tym samym każde zachowanie skierowane przeciwko życiu człowieka narusza normę sankcjonowaną i jeżeli nie jest usprawiedliwione podstawową kolizją z innym dobrem chronionym konstytucyjnie, to pozostaje zachowaniem bez-

Przepisy unijnego prawa obligują państwa członkowskie stosownie do art. 17 rozporządzenia nr 178/2002 oraz art. 55 rozporządzenia (WE) nr 882/2004 Parlamentu Europejskiego i Rady z dnia 29 kwietnia 2004 r. w sprawie kontroli urzędowych przeprowadzanych w celu sprawdzenia zgodności z prawem paszowym i żywnościowym oraz regułami dotyczącymi zdrowia zwierząt i dobrostanu zwierząt (Dz.Urz. UE L 165 z dnia do określenia sankcji za naruszenie prawa żywnościowego, które muszą być skuteczne, proporcjonalne i odstraszające.

$6 \quad$ Wyrok z dnia 23 kwietnia 2000r. sygn.. akt K 23/99.

$7 \quad$ M. Cieślak, (w:) System prawa karnego , t. IV, cz.1., Wrocław 1985, s. 291-292.

8 Sygn. akt IV KR 15/89, Orzecznictwo Sądów Polskich i Komisji Arbitrażowych 1990 nr 2, poz. 234. 
prawnym ${ }^{9}$. Stosownie do tego Trybunał Konstytucyjny w uzasadnieniu orzeczenia z 28 maja 1997 r. stwierdził: demokratyczne państwo prawa jako naczelna wartość stawia człowieka i dobra dla niego najcenniejsze. Dobrem takim jest życie, które $w$ demokratycznym państwie prawa musi pozostawać pod ochronq konstytucyjnq i dalej ustawodawca zwykty nie może wprowadzać ograniczeń $i$ warunków w prawnej ochronie życia, ograniczających działanie normy konstytucyjnej. W szczególności nie może uzależnić ochrony życia od zakresu wydanej przez siebie normy sankcjonowanej stwierdzając dalej, że ochrona życia ludzkiego nie może być rozumiana wytącznie jako ochrona minimum funkcji biologicznych niezbędnych do egzystencji, ale jako gwarancja prawidłowego rozwoju, a także uzyskania $i$ zachowania normalnej kondycji psychofizycznej, właściwej dla danego wieku rozwojowego. Biorąc na siebie ciężar pozytywnego obowiązku w tym zakresie ustawodawca polski stworzył katalog czynów zabronionych pod groźbą kary.

\section{Karnoprawne podstawy odpowiedzialności na gruncie ustawy o bezpieczeństwie żywności i żywienia}

Odpowiedzialność typu penalnego w zakresie prawa żywnościowego ma na celu ochronę życia i zdrowia człowieka oraz zabezpieczenia przed szkodliwym oddziaływaniem czynników zewnętrznych tj. chemicznych, biologicznych i fizycznych, a także przed skutkami nieprawidłowego żywienia ${ }^{10}$. Ma na celu zapewnienie odpowiedniego standardu żywności, która dopuszczona jest do obrotu. Nie chodzi tu o celowe działanie z zamiarem zabójstwa ${ }^{11}$. Odpowiedzialność w prawie żywnościowym koncentruje się na etapie wytwarzania i dopuszczania do obrotu żywności, tak aby zapewnić odpowiedni jej standard.

Głównym źródłem odpowiedzialności karnej sensu stricto w prawie żywnościowym stanowią normy zawarte w art. 96-99 ustawy z dnia 25 sierpnia 2006 r. o bezpieczeństwie żywności i żywienia ${ }^{12}$, która to ustawa zastąpiła ustawę z dnia 11 maja 2001 r. o warunkach zdrowotnych żywności i żywienia ${ }^{13}$. Regulacja ta stanowiła konieczność dostosowania przepisów krajowych do rozporządzeń unijnych $^{14}$, co wskazano w uzasadnieniu do projektu ustawy ${ }^{15}$. Ustawa ta w swej treści stosownie do art. 1 ust. 1 u.b.ż.ż. określa wymagania niezbędne dla zapewnienia bezpieczeństwa żywności i żywienia oraz przepisy kompetencyjne umożliwiające pra-

\footnotetext{
$9 \quad$ A. Zoll, (w:) Zoll (red.), Kodeks karny, t. II, Warszawa 2017, s. 251.

10 H. Gertig, G. Duda, Żywność a zdrowie i prawo, Warszawa 2004.

11 Chociaż od wieków żywność była wykorzystywana jako narzędzie, za pomocą którego dokonywano przestępstwa.

Dz.U. z 2018 r., poz. 1541

Dz.U. z 2005 r., poz. 265.

Rozporządzenie Parlamentu Europejskiego i Rady z dnia 29 kwietnia 2004 roku nr 852/2004/WE w sprawie higieny środków spożywczych (Dz.U. L 139 z 30 kwietnia 2004 r. s. 1) oraz nr 882/2004/WE.

15 http://orka.sejm.gov.pl/Druki5ka.nsf/0/1F36EA08F933F242C125716C003BE87F/\$file/573.pdf (dostęp dnia: 02.12 .2018 r.).
} 
widłowe stosowanie wymienionych rozporządzeń wspólnotowych. Jednym z mechanizmów służących realizacji tego celu jest sankcja prawnokarna za naruszenie przepisów ustawy. Przepisy karne znajdują się w rozdziale pierwszym działu VIII ustawy. W uzasadnieniu projektodawca stwierdza, że w krajach Unii Europejskiej przepisy przewidują kary finansowe za złamanie przepisów z zakresu prawa żywnościowego. Jednak krajowa regulacja dotycząca tej materii wymaga opatrzenia jej w sankcję karną. Niewystarczające okazały się regulacje z zakresu kodeksu wykroczeń, ponieważ nie gwarantują odpowiedniego standardu ochrony konsumentów ${ }^{16}$. Niewątpliwie projektodawca wskazuje na funkcję ochronną oraz prewencyjną, jednak metoda legislacyjna przyjęta przez ustawodawcę budzi wątpliwości doktryny, na co wskazuje m.in. P. Ochman ${ }^{17}$. Główne zarzuty dotyczące techniki legislacyjnej, ogniskują się na kaskadowym ujęciu norm sankcjonowanych, co nasuwa pytanie o zgodność regulacji z zasadą nullum crimen sine lege certa oraz nullum crimen sine lege stricta, a także powoduje wątpliwości dotyczące nadmiernej kazuistyki.

Stanowisko to wymaga rozwinięcia. Za przykład niech posłuży jeden z typów czynów zabronionych - art. 96 ust. 1 u.b.ż.ż. (typ podstawowy) ust. 3 (typ kwalifikowany przez okoliczności o charakterze statycznym) oraz ust. 4 (typ czynu zabronionego charakteryzujący się nieumyślnością) ${ }^{18}$.

\section{Strona przedmiotowa}

Zewnętrzne zachowanie się sprawcy stosownie do zasady cognationis poenam nemo patitur przywołanego czynu zabronionego polega na produkowaniu lub wprowadzaniu do obrotu środka spożywczego powszechnie spożywanego, szkodliwego dla zdrowia lub życia człowieka. Jak można zauważyć, czynności wykonawcze stypizowanego czynu zabronionego ujęte są za pomocą znamion ocennych i nieostrych. Czynności te ujęte są alternatywnie - w przypadku gdy zachowanie podlegające prawnokarnej ocenie sprawcy wypełniać będzie oba znamiona czynności wykonawczych niewątpliwie sprawca odpowie za jedno przestępstwo, co jednak może mieć wpływ na stopień społecznej szkodliwości czynu i będzie brane pod uwagę w ramach dyrektyw sądowego wymiaru kary. Ze względu na nieostre pojęcia poszukiwać ich wytłumaczenia należy w słowniczku ustawowym. I tak przez produk-

16 Ibidem.

17 P. Ochman, Kilka uwag o przepisach karnych ustawy o bezpieczeństwie żywności i żywienia, (w:) Przeciwdziałanie patologiom na rynku żywności, A. Lewkowicz, W. Pływaczewski (red.), Szczytno 2015, s. 274.

$18 \quad$ Art. 96 1. Kto produkuje lub wprowadza do obrotu środek spożywczy powszechnie spożywany szkodliwy dla zdrowia lub życia człowieka, podlega grzywnie, karze ograniczenia wolności albo pozbawienia wolności do lat 2. 2. Kto produkuje lub wprowadza do obrotu, szkodliwy dla zdrowia lub życia człowieka, środek spożywczy specjalnego przeznaczenia żywieniowego, suplement diety lub nową żywność, podlega grzywnie, karze ograniczenia wolności albo pozbawienia wolności do lat 3. 3. Jeżeli sprawca uczynił sobie z popełnienia przestępstwa określonego w ust. 1 lub 2 stałe źródło dochodów albo dopuszcza się przestępstw określonych w ust. 1 i 2 w stosunku do środków spożywczych o znacznej wartości, podlega karze pozbawienia wolności od 6 miesięcy do lat 5. 4. Jeżeli sprawca czynów określonych w ust. 1 lub 2 działa nieumyślnie, podlega grzywnie, karze ograniczenia wolności albo pozbawienia wolności do roku. 
cję środków spożywczych należy rozumieć - zgodnie z art. 3 ust. 3 pkt. 29 u.b.ż.ż. - czynności obejmujące przygotowywanie surowców do przerobu, ich przechowywanie, poddawanie procesom technologicznym, pakowanie i znakowanie oraz wszelkie inne czynności związane z przygotowywaniem do obrotu, a także przechowywanie wyrobów gotowych do czasu wprowadzenia ich do obrotu. Należy stwierdzić, że tak ujęta definicja produkcji jest znacznie szersza od powszechnego znaczenia - co więcej, w jej obrębie znajduje się również przechowywanie wyrobów, co wydaje się być daleko idącym rozszerzeniem granic odpowiedzialności karnej. Ilekroć ustawodawca konstruuje typy czynów zabronionych w ustawach szczególnych, w części nieuregulowanej ustawą szczególną zastosowanie znajduje Część Ogólna Kodeksu karnego tj. przepisy art. od 1 kk. do 115 kk. Stąd wywodzić należy, iż na gruncie polskiego prawa karnego, zgodnie z dyspozycją przepisu art. $16 \S 2 \mathrm{kk}$. przygotowanie karalne jest wówczas gdy ustawa tak stanowi. W świetle powyższego za wątpliwe należy uznać zdefiniowanie przez ustawodawcę jednej z czynności sprawczych produkcji środków spożywczych za przygotowanie, co godzi w zasadę lege non distinguente nec nostrum est distinguere.

Drugi z alternatywnie ujętych czynności wykonawczych, czyli wprowadzanie środka do obrotu jest kolejnym etapem po wyprodukowaniu, definicja tego pojęcia również znajduje się w ustawie w art. 3 ust. 3 pkt 52 jednak w tym zakresie następuje odesłanie do art. 3 pkt 8 Rozporządzenia nr 178/2002. Tak kaskadowe ujęcie czynności sprawczej należy uznać za budzące istotne wątpliwości natury konstytucyjnej w zakresie konstruowania typów czynów zabronionych. Odnosząc się więc do przywołanego rozporządzenia, wprowadzanie żywności do obrotu to „wprowadzanie na rynek", które oznacza posiadanie żywności w celu sprzedaży, z uwzględnieniem oferowania do sprzedaży lub innej formy dysponowania, bezpłatnego lub nie, oraz sprzedaż, dystrybucję i inne formy dysponowania. Co ciekawe znamię wprowadzania do obrotu pojawia się w licznych normach prawnokarnych budząc wątpliwości interpretacyjne co do tego, czy należy je traktować wąsko czy szeroko. Jednak wydaje się, że skoro ustawodawca posłużył się definicją legalną - choć niedoskonałą - to zgodnie z zakazem wykładni rozszerzającej norm prawa karnego, należy interpretować znaczenie tego pojęcia w taki sposób, jaki nadała mu przywołana dyrektywa - nieprecyzyjna i szeroka. Odwołując się do powszechnym znaczeniu tak ujętych czynności sprawczych produkowania i wprowadzania i zestawiając to znaczenie z szerokimi definicjami legalnymi, obejmującymi swoimi desygnatami również posiadanie, należy uznać rozszerzenie odpowiedzialności karnej za znaczne, gdyż w braku jego wyróżnienia przez ustawodawcę takie zachowanie należałoby zakwalifikować jako stadium iter delicti jedynie fazę bezkarnego(!) przygotowania. W praktycznym aspekcie największe znaczenie będą miały czynności związane z przenoszeniem władztwa nad towarami ${ }^{19}$.

19 M. Mozgawa (red.), Pozakodeksowe przestępstwa przeciwko zdrowiu, Warszawa 2017, s. 450. 
Przedmiotem czynności sprawczych jest środek spożywczy szkodliwy dla zdrowia. Wyjaśnienie tego pojęcia wymaga odwołania się do zakresu pojęciowego środka spożywczego, które znajduje swoją definicję ustawową w art. 3 ust. 1. Przepis ten stanowi, że jest nim każda substancja lub produkt w rozumieniu art. 2 rozporządzenia nr 178/2002 ${ }^{20}$. Zaś środek spożywczy powszechnie spożywany i szkodliwy dla zdrowia lub życia jest zdefiniowany w art. 3 ust. 3 pkt 44 u.b.ż.z. ${ }^{21}$ Ergo jest to taki środek spożywczy powszechnie spożywany, którego skonsumowanie może spowodować negatywne skutki dla życia lub zdrowia człowieka. Przy czym ustawodawca wymienia jedynie przykładowe przyczyny owej szkodliwości. Niewątpliwie za takie należy uznać produkty dostępne powszechnie - takie, które w normalnym toku rzeczy spożywane są przez konsumentów, a które mogłyby ze względu na ich szkodliwość spowodować negatywne skutki.

Czyn zabroniony z art. 96 ust. 1 u.b.ż.ż. charakteryzuje się umyślnością, może być popełniony zarówno z zamiarem bezpośrednim (dolus directus) jak i zamiarem wynikowym ( dolus eventualis) w obu formach sprawczych tj. zarówno co do wyprodukowania, jak i wprowadzenia do obrotu. Występek ten ma charakter formalny i może być popełniony jedynie przez działanie ${ }^{22}$. Zgodnie $w$ doktrynie podnosi się, iż przestępstwo to należy zakwalifikować jako przestępstwo abstrakcyjnego narażenia na niebezpieczeństwo, co oznacza, że zagrożenie dla dobra prawnego ma charakter potencjalny i jest jedynie racją wprowadzenia karalności określonego zachowania. Wystąpienie niebezpieczeństwa nie wymaga więc udowodnienia dla przyjęcia realizacji znamion typu czynu zabronionego ${ }^{23}$. Nie można jednak wykluczyć, że skutek w postaci realnego naruszenia dóbr będących przedmiotem ochrony wystąi, co będzie implikowało rozpatrzenie kwestii zbiegów odpowiedzialności za inne przestępstwa, o czym później.

Środek spożywczy to jakiekolwiek substancje lub produkty, przetworzone, częściowo przetworzone lub nieprzetworzone, przeznaczone do spożycia przez ludzi lub, których spożycia przez ludzi można się spodziewać. „Środek spożywczy" obejmuje napoje, gumę do żucia i wszelkie substancje, łącznie z wodą, świadomie dodane do żywności podczas jej wytwarzania, przygotowania lub obróbki. Definicja ta obejmuje wodę zgodną z normami określonymi zgodnie z art. 6 dyrektywy 98/83/WE i bez uszczerbku dla wymogów dyrektyw 80/778/EWG i 98/83/ WE. „Środek spożywczy” nie obejmuje: a) pasz; b) zwierząt żywych, chyba że mają być one wprowadzone na rynek do spożycia przez ludzi; c) roślin przed dokonaniem zbiorów; d) produktów leczniczych w rozumieniu dyrektyw Rady 65/65/EWG i 92/73/EWG; e) kosmetyków w rozumieniu dyrektywy Rady 76/768/EWG; f) tytoniu i wyrobów tytoniowych w rozumieniu dyrektywy Rady 89/622/EWG; g) narkotyków lub substancji psychotropowych w rozumieniu konwencji o środkach odurzających z 1961 r. oraz konwencji o substancjach psychotropowych z 1971 r.; h) pozostałości i zanieczyszczeń.

21 Środek spożywczy szkodliwy dla zdrowia lub życia człowieka - środek spożywczy, którego spożycie w warunkach normalnych i zgodnie z przeznaczeniem może spowodować negatywne skutki dla zdrowia lub życia człowieka, w szczególności, jeżeli: a) nie spełnia wymagań zdrowotnych określonych w dziale II, b) zawiera: - substancje zanieczyszczające lub zanieczyszczenia mikrobiologiczne w ilościach przekraczających dopuszczalne poziomy określone w rozporządzeniach Unii Europejskiej oraz inne zanieczyszczenia-pozostałości skażeń promieniotwórczych w ilościach przekraczających poziomy określone w rozporządzeniach Unii Europejskiej-weterynaryjne produkty lecznicze w ilościach przekraczających dopuszczalne poziomy lub zabronione określone w rozporządzeniach Unii Europejskiej-inne substancje szkodliwe dla zdrowia lub życia człowieka określone w przepisach Unii Europejskiej.

23 W. Wróbel, A. Zoll, Prawo karne, Kraków 2010, s. 188. 
Problematyka karnoprawnej ochrony życia i zdrowia w oparciu o naruszenie prawa...

\section{Strona podmiotowa}

Bez wątpienia ratio legis penalizacji występków z ustawy o bezpieczeństwie żywności i żywienia przemawia za uznaniem powszechnego charakteru przestępstwa. Zawężanie odpowiedzialności do indywidualnego charakteru, ograniczając ją wyłącznie do podmiotów trudniących się w sposób profesjonalny dystrybucją żywności nie znajduje uzasadnienia. Ponadto należy zwrócić uwagę na problematykę związaną z odpowiedzialnością osób prawnych i innych podmiotów ustawowych. Faktem jest, że odpowiedzialności karnej sensu stricto na gruncie prawa polskiego podlegają wyłącznie osoby fizyczne. Czyny stypizowane w ustawie nie są objęte działaniem ustawy z dnia 28 października 2002 r. o odpowiedzialności podmiotów zbiorowych za czyny zabronione pod groźbą kary ${ }^{24}$. A jednak bardzo często produkcją żywności w skali masowej trudnią się właśnie przedsiębiorstwa, tym samym w takim wypadku odpowiedzialność będą ponosić wyłącznie osoby fizyczne odpowiedzialne za jego działalność. Nie można wykluczyć sytuacji, że ad casum pociągnięcie do odpowiedzialności samego właściciela przedsiębiorstwa czy dyrektora głównego ze względu na brak możliwości przypisania im zamiaru będzie niemożliwe, zaś jednostki bezpośrednio odpowiedzialne za produkcję taką odpowiedzialność poniosą, ponieważ będą miały zamiar jego popełnienia, to jest chcą go popełnić, albo przewidując możliwość popełnienia, na to się godzą.

\section{Sankcje}

Występki te zagrożone są grzywną, karą ograniczenia wolności albo pozbawieniem wolności do lat 2. Jeżeli kara pozbawienia wolności orzeczona zostanie w wymiarze nieprzekraczającym roku, może być warunkowo zawieszona. Ponadto istnieje również możliwość warunkowego umorzenia postępowania karnego. Możliwe jest również odstąpienie od wymierzenia kary (art. 59 kk.), oczywiście po spełnieniu przesłanki materialnej nieznaczności społecznej szkodliwości czynu). Niewykluczone jest również stosowanie środków karnych takich jak: zakaz prowadzenia określonej działalności gospodarczej, podanie wyroku do publicznej wiadomości czy zakaz zajmowania określonego stanowiska lub wykonywania określonego zawodu. Niewykluczone jest również orzeczenie przepadku oraz nałożenie obowiązku naprawienia szkody lub zadośćuczynienia za doznaną krzywdę $e^{25}$.

\section{Problem zbiegu przepisów}

Sytuacja zbiegu przepisów ustawy zachodzi, gdy ten sam czyn w znaczeniu naturalnym, a więc zachowanie wywołujące zmianę w świecie zewnętrznym, realizu- 
je znamiona różnych typów czynów zabronionych. Stosownie do art. 11 kk. ten sam czyn może stanowić tylko jedno przestępstwo, jednak zgodnie z $§ 2$ jeżeli czyn wyczerpuje znamiona określone $\mathrm{w}$ dwóch albo więcej przepisach ustawy karnej, sąd skazuje za jedno przestępstwo na podstawie wszystkich zbiegających się przepisów. W stosunku do przestępstwa z art. 96 u.b.ż.ż. niewykluczone jest wystąpienie zbiegu pomijalnego rozwiązanego na zasadzie konsumpcji, gdzie przepisem konsumującym będzie art. $165 \S 1$ pkt 2 kk., ze względu na wyższe zagrożenie karą ${ }^{26}$. Nie można wykluczyć kumulatywnej kwalifikacji prawnej w przypadku osiągnięcia przez sprawcę skutku, w postaci wywołania rozstroju zdrowia bądź zagrożenia życia z przepisami art. 96 ust. $1 \mathrm{w}$ zw. z art. 156 § 1 lub 157 § 1 lub 2 kk. lub 155 kk. lub 148 k.k. w zw. z art. 11 § 2 kk. Nie można również wykluczyć idealnego zbiegu przepisów art. 96 u.b.ż.ż. z przepisami art. 110, 111 czy 136 kw.

W związku z tym powstaje odpowiedź na pytanie, jak daleko w zakresie ius puniendi może posunąć się ustawodawca w obliczu zmieniającej się rzeczywistości społeczno-gospodarczej. Z drugiej strony ustawodawca Unijny zobligowany jest na mocy traktatów do postępowania zgodnie z zasadami proporcjonalności i subsydiarności (art. 5 ust. 2 i ust. 3 TUE). Ustawodawca krajowy konstruując typ czynu zabronionego, musi opierać się o jego z punktu widzenia materialnej ujemnej treści daleko posuniętą generalizacją, która to zawierać będzie jedynie elementy konstytutywne dla tej ujemnej treści. Zbytnia indywidualizacja czynu jest niepożąanego. Przestępstwa te są przestępstwami formalnymi - abstrakcyjnego narażenia dobra prawnego na niebezpieczeństwo. Dokonując kwalifikacji prawnej czynu, sąd musi każdorazowo badać modus operandi sprawcy. Należy rozważyć czy rozciągnięcie odpowiedzialności karnej na czynności sprawcze objęte normą sankcjonowaną art. 96 u.b.ż.ż, które de facto w porównaniu do wyżej wymienionych przepisów ustawy karnej nie stanowią zbyt daleko posuniętej ingerencji prawnokarnej, godzącej w zasady demokratycznego państwa prawnego. Czy cel ochronny nie zostałby spełniony, gdyby dobra te, jakimi są życie i zdrowie - niewątpliwie w hierarchii dóbr indywidualnych zasługujących na ochronę - były chronione wyłącznie przywołanymi przepisami Kodeksu karnego, zaś w pozostałym zakresie niejako iter delicti, kiedy bezpośredniość zamachu na wskazane dobra jest jeszcze znacznie oddalona, tak jak większość państw członkowskich posłużyć się odpowiedzialnością administracyjną oraz cywilną.

\section{Ne bis in idem}

W sytuacji, kiedy dochodzi do zbiegu przepisów regulujących wyłącznie odpowiedzialność karną, problematyka zbiegów znajduje swoje rozwiązanie poprzez 
reguły kolizji norm wypracowane na podstawie przepisów ustawy kodeks karny. Na gruncie ustawy o bezpieczeństwie żywności i żywienia może jednak dość do zbiegu wykroczenia z art. $100^{27} \mathrm{z}$ deliktami administracyjnym z zakresu regulacji prawa żywnościowego ${ }^{28}$. Powoduje to sytuację, w braku wyraźnie wypracowanych reguł kolizyjnych, możliwości pociągnięcia sprawcy do odpowiedzialności zarówno karnej, jak i administracyjnej z tytułu tego samego czynu. O ile odpowiedzialność typu penalnego - mająca efekt stygmatyzacji - powinna mieć zastosowanie do zachowań, które niosą w sobie ujemny ładunek oceny, zaś jej wprowadzanie i stosowanie musi znajdować oparcie w gwarancjach konstytucyjnych, to odpowiedzialność administracyjna o charakterze represyjnym w takie gwarancje nie jest zaopatrzona, a jej stosowanie uzależnione jest od obiektywnej oceny niedopełnienia powinności wynikającej z prawa materialnego administracyjnego, bez względu na jego ocenę moralną oraz podmiotowe ukierunkowanie sprawcy deliktu administracyjnego. Konieczne jest zatem rozgraniczenie przez ustawodawcę poprzez dokonanie wyboru i usankcjonowania danego zachowania, bądź w oparciu sankcję administracyjną, bądź w oparciu o sankcję karną, gdyż obie są z gruntu odmienne. Sankcja karna jako ultima ratio, powinna być stosowana w ostateczności. Wydaje się, że współistnienie w polskim porządku prawnym, w zakresie prawa żywnościowego zarówno odpowiedzialności typu penalnego jak i administracyjnego stanowi system mało spójny ${ }^{29}$. Trudno wytłumaczyć racjonalnie przyjęcie takiej techniki legislacyjnej, gdyż de facto współistnienie obu reżimów daje możliwość zastosowania obu tych dolegliwości, co jest sprzeczne z fundamentalnymi założeniami ustrojowymi demokratycznego państwa prawnego i sprzeczne z gwarantowaną konstytucyjnie zasadą ne bis in idem, wywodzoną z art. 2 Konstytucji RP. Jedynym argumentem przemawiającym za utrzymaniem owego dualizmu jest fakt, iż na gruncie reżimu administracyjnego istnieje możliwość pociągnięcia do odpowiedzialności osób prawnych oraz innych jednostek organizacyjnych nieposiadających osobowości prawnej, którym ustawa przyznaje zdolność prawną, w odróżnieniu od odpowiedzialności karnej, którym ustawa przyznaje zdolność prawną, w odróżnieniu od odpowiedzialności karnej.

\section{Podsumowanie}

Żywność była stosowana jako narzędzie służący do popełniania przestępstw przeciwko życiu i zdrowiu na wiele lat przed powstaniem regulacji w zakresie prawa żywnościowego, a penalizacja tych zachowań następowała na podstawie przepisów regulujących przestępstwo zabójstwa czy narażanie na niebezpieczeństwo bądź

27 Art. 100 u.b.ż.ż.: Kto: 1) używa do produkcji lub wprowadza do obrotu środek spożywczy po upływie terminu przydatności do spożycia lub daty minimalnej trwałości [...] podlega karze grzywny.

28 P. Wojciechowski, Z problematyki odpowiedzialności administracyjnej i karnej w prawie żywnościowym, „Przegląd Prawa Rolnego" 2011 nr 1, s. 67 i nast. $29 \begin{aligned} & \text { M. Trempała, Odpowiedzialność administracyjna sprzedawcy detalicznego za wprowadzanie do obrotu artykułu } \\ & \text { rolno-spożywczego sfałszowanego, „Przegląd Prawa Rolnego” } 2012 \mathrm{nr} 2 \text {, s. } 141 \text { i nast. }\end{aligned}$ 
umyślnych zamachów na zdrowie człowieka. Prawo żywnościowe jest prężnie rozwijająca się dziedziną, która u swych celów stawia ochronę życia i zdrowia. Ochrona ta jednak dotyczy procesu produkcji i wprowadzania żywności do obiegu, tak aby zapewnić minimalny standard ochrony dla konsumentów. Ilekroć ustawodawca staje przed koniecznością formułowania norm prawnokarnych, w istocie musi dokonać wyboru i ważenia dóbr ze względu na ultima ratio polityki penalnej w demokratycznym państwie prawnym. Przepisy karne zawarte w ustawie o bezpieczeństwie żywności i żywienia, choć istotnie ważne z punktu widzenia wymogu skuteczności respektowania tej regulacji przez ich adresatów, wykazują jednak wiele mankamentów m.in. w zakresie techniki legislacyjnej, wobec czego należy zgłosić dezaprobatę, ze względu na specyfikę materii jaką są normy karne. Warto zwrócić uwagę na orzeczenie Trybunału Konstytucyjnego, w którym wskazano, że prawo karne stwarza dla wtadzy w demokratycznym państwie prawa barierę, poza którq obywatel powinien czuć się bezpieczny w tym sensie, że bez przekroczenia pola zabronionego pod groźbq kary nie może być pociqgnięty do odpowiedzialności karnej. Prawo karne ma wyznaczać wyraźne granice między tym, co jest dozwolone, a tym co jest zabronione ${ }^{30}$.

Ponadto istotnym problemem $\mathrm{w}$ zakresie ryzyka związanego $\mathrm{z}$ działalnością wytwórczą w zakresie żywności jest postępujący kryzys jakości żywności (food security). Przyczyną, która powoduje jego powstanie jest chęć uzyskania zysku za jak najniższą cenę, a także wzajemne oddziaływanie rynków w skali międzynarodowej, a także oddziaływanie czynników naturalnych, w związku z postępującym zanieczyszczeniem ziemi. Żywność taka może doprowadzić do takich samych skutków jak żywność niebezpieczna tj. do zagrożenia dla zdrowia. Chodzi więc o problem adekwatności jakości pojedynczego produktu, tak aby chęć osiągnięcia zysku małym kosztem nie stanowiła zagrożenia dla zdrowia ludzkiego w stopni wyższym niż żywność całkowicie niezdatna do konsumowania, przez wywoływanie m.in. powszechnego zjawiska nadwagi. Powstaje pytanie czy istnieje możliwość dokonania oceny karnoprawnej takiego działania, aby móc skutecznie zapobiegać zjawisku kryzysu bezpieczeństwa żywności. Niewątpliwie jest to zadanie trudne z uwagi na konieczność dokonywania oceny skutków długofalowych, co może w zasadzie uniemożliwić penalizację takich zachowań na podstawie obowiązującej regulacji. $\mathrm{Na}$ gruncie obowiązującej ustawy przestępstwa tam stypizowane są przestępstwami o charakterze formalnym, które odnoszą się wyłącznie do sytuacji, w której żywność jest żywnością niebezpieczną. Wynika z tego, że nie obejmuj swym zakresem zastosowania produkowania i wprowadzania do obrotu żywności słabej jakości, która przynieść może w istocie takie same skutki. Tym samym wymyka się poza zakres zastosowania ustawy o bezpieczeństwie żywności i żywienia, a wydaje się, 
że również tego rodzaju potencjalne ryzyko związane z obrotem żywnością było przedmiotem zainteresowania projektodawcy ustawy, na co wskazywał w uzasadnieniu do projektu. Pociągnięcie do odpowiedzialności za ów skutek w postaci naruszenia zdrowia czy życia na podstawie kodeksu karnego również jest w zasadzie niemożliwe. De lege ferenda istotne jest więc uregulowanie tego problemu, skoro ustawodawca polski decyduje się na usankcjonowanie działań na przedpolu zamachu w postaci występków abstrakcyjnego narażenia na niebezpieczeństwo. Złożoność problemu ukazuje, że współczesne prawo karne staje przed koniecznością redefiniowania pojęcia zamachów na życie i zdrowie, gdyż potencjalne zamachy na te dobra obecnie pochodzić mogą z wielu nieznanych dotąd źródeł. Konieczne jest zatem - stosownie do zasady proporcjonalności i funkcji gwarancyjnej - takie ukształtowanie regulacji karnej w tym zakresie, aby móc skutecznie przeciwdziałać bezprawnym zamachom na dobra będące przedmiotem ochrony wskazanej w pracy regulacji. Co do zarzutu naruszenia zasady ne bis indem należy również pochylić się nad doprowadzeniem do ujednolicenia systemu odpowiedzialności w prawie żywnościowym, gdyż obecnie jest on niespójny i jego funkcjonowanie w obecnym kształcie godzi w podstawowe zasady państwa prawa. Problem jest o tyle palący, że żywność stanowi nieodłączny element życia ludzkiego, które jest przedmiotem ochrony przywołanych przeze mnie norm. 


\section{PENAL LIABILITY BASED ON FOOD LAW REGULATION}

Keywords: food law, penal law, penal liability, health and life

The article attempts to shine a light on criminal law concerning Food Law. The point is to place the policies, regulations to protect the life, health issues in the Polish legal system. It focuses on Criminal liability for the production or marketing of harmful foodstuff and shows issues related to aspects underlining the problem. It also deliberated proposed changes in modifying food law to provide guarantees related to the application of criminal sanctions and to achieve necessary standard of democracy in criminal policy. It reveals significant issues with food quality (issues in food policy).

\section{Bibliografia:}

Cieślak M., (w:) System prawa karnego, t. IV, cz. 1, I. Andrejew, L. Kubicki, J. Waszczyński, (red.) Wrocław 1985.

Gertig H., Duda G., Żywność a zdrowie i prawo, Warszawa 2004.

Ochman P., Kilka uwag o przepisach karnych ustawy o bezpieczeństwie żywności i żywienia, (w:) Przeciwdziałanie patologiom na rynku żywności, Lewkowicz A., Pływaczewski W. (red.), Szczytno 2015.

Mozgawa M. (red.), Pozakodeksowe przestępstwa przeciwko zdrowiu, Warszawa 2017.

Trempała M., Odpowiedzialność administracyjna sprzedawcy detalicznego za wprowadzanie do obrotu artykułu rolno-spożywczego sfałszowanego, „Przegląd Prawa Rolnego” 2012, nr 2.

Wojciechowski P., Z problematyki odpowiedzialności administracyjnej i karnej w prawie żywnościowym, „Przegląd Prawa Rolnego” 2011 nr 1.

Wrzosek K. Prawnokarna ochrona zdrowia społeczeństwa przed niebezpiecznymi produktami żywnościowymi (spożywczymi), (w:) System prawa karnego. Tom 11, Bojarski M. (red.), Warszawa 2017.

Zoll A., (w:) Zoll A. (red.), Kodeks karny, t. II, Warszawa 2017. 